\title{
Abundant Expression of Parathyroid Hormone-related Protein in Primary Rat Aortic Smooth Muscle Cells Accompanies Serum-induced Proliferation
}

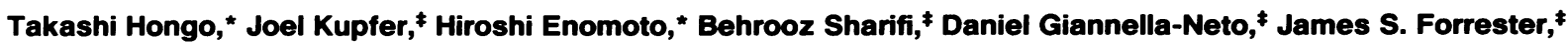 \\ Frederick R. Singer, ${ }^{*}$ David Goltzman," Geoffrey N. Hendy, Carlos Pirola," James A. Fagin,"* and Thomas L. Clemens" \\ Divisions of Endocrinology* and Cardiology, ${ }^{\ddagger}$ Department of Medicine, Cedars-Sinai Medical Center, University of California, Los \\ Angeles, Los Angeles, California 90048; and Departments of Medicine and Physiology, ${ }^{\S}$ McGill University, Montreal, Quebec, Canada
}

\begin{abstract}
Parathyroid hormone-related protein (PTHrP), which is responsible for producing hypercalcemia in patients with humoral hypercalcemia of malignancy, has recently been identified in several normal tissues. Because PTHrP, like parathyroid hormone (PTH), is known to exhibit vasodilatory properties, we investigated the expression and regulation of PTHrP mRNA in cultured rat aortic smooth muscle cells (SMC). We report here that PTHrP mRNA is expressed in SMC and is markedly induced by serum in a time- and concentration-dependent fashion. Addition of $10 \%$ fetal calf serum to serum-deprived, confluent cells, resulted in a marked induction of PTHrP mRNA by $2 \mathrm{~h}$ with a peak at 4-6 h. PTHrP was detected in SMC by immunocytochemistry and radioimmunoassay of conditioned medium, and was shown to be up-regulated within $24 \mathrm{~h}$ after the addition of serum. The serum induction of PTHrP mRNA was blocked by actinomycin D and by cycloheximide indicating the need for protein synthesis to evoke the serum effect on PTHrP gene transcription. In addition, treatment with dexamethasone, which has been previously shown to reduce the constitutive expression of PTHrP in human cancer cells, also blunted the serum induction of PTHrP mRNA in SMC. Treatment of quiescent cells with the serum mitogens platelet-derived growth factor or insulin-like growth factor-I had no effect on PTHrP, whereas the vasoactive peptides endothelin, norepinephrine and thrombin stimulated PTHrP expression. Exogenous addition of recombinant PTHrP-(1-141) had no significant effect on SMC DNA synthesis as measured by $\left[{ }^{3} \mathbf{H}\right]$ thymidine incorporation. In summary, the abundance of PTHrP mRNA and the characteristics of its regulation in SMC suggest a major role for PTHrP as a local modulator in vascular smooth muscle. (J. Clin. Invest. 1991. 88:1841-1847.) Key words: gene transcription - hypercalcemia of malignancy • messenger RNA • vascular smooth muscle
\end{abstract}

\section{Introduction}

The parathyroid hormone-related protein $(\mathrm{PTHrP})^{1}$ has recently been isolated from human tumors associated with the

A portion of this work has appeared in abstract form (1991. Clin. Res. 39:98A).

Address reprint requests to Dr. Clemens, Bone Center, CedarsSinai Medical Center, 444 South San Vicente Boulevard, Los Angeles, CA 90048.

Received for publication 13 October 1990 and in revised form 18 June 1991.

J. Clin. Invest.

(C) The American Society for Clinical Investigation, Inc.

0021-9738/91/12/1841/07 \$2.00

Volume 88, December 1991, 1841-1847 syndrome of humoral hypercalcemia of malignancy (1-3). The protein shares sufficient amino-terminal homology with parathyroid hormone (PTH) that it can activate PTH receptors in target cells (4-6) and thereby cause hypercalcemia in patients harboring PTHrP-producing tumors. However, PTHrP is the product of a unique gene $(7,8)$ and its mRNA transcripts are present not only in tumor tissue $(9,10)$ but also in normal endocrine and nonendocrine tissues (11-13). Although a definitive role for PTHrP in normal cell physiology has not been established, emerging evidence suggests that it might have predominantly local actions.

It is well established that both PTH and PTHrP are vasorelaxant in vivo, and vascular tissue (14) and vascular smooth muscle cells (SMC) appear to possess specific receptors for these peptides $(14,15)$. In order to investigate further a possible role for PTHrP in vascular smooth muscle, we have studied PTHrP gene expression in cultured aortic SMC. Our studies show that PTHrP and its mRNA are expressed at relatively low abundance in serum-deprived cells, but are markedly induced after repletion of cells with serum. The magnitude and timecourse of the serum induction of PTHrP mRNA in vascular SMC suggest that PTHrP may be a locally bioactive factor involved in the paracrine control of contractility or differentiation in this tissue.

\section{Methods}

Materials. Human recombinant PTHrP [PTHrP-(1-141)] was a generous gift from William Wood, Genentech Corp., South San Franscisco, CA. Bovine parathyroid hormone (Tyr-34) 1-34 amide [PTH-(134) $\mathrm{NH}_{2}$ ] and platelet-derived growth factor (PDGF) were purchased from Bachem, Torrance CA. Insulin-like growth factor-I (IGF-I) was from Amgen, Inc., Thousand Oaks, CA, and dexamethasone (DEX), endothelin-I, thrombin, and norepinephrine were purchased from Sigma Chemical Co., St. Louis, MO. 1,25-Dihydroxyvitamin $D_{3}[1,25-$ $(\mathrm{OH})_{2} \mathrm{D}_{3}$ ] was kindly provided by Dr. Milan Uskokovic, HoffmannLaRoche, Inc., Nutley, NJ. All other reagents were molecular biological grade.

Primary smooth muscle cell cultures. Medial SMC were isolated from 200-g male Sprague-Dawley rats and cultured by the procedure described by Chamley-Campbell et al. (16) with minor modifications. Cells were isolated by removing the adventitia with forceps under a dissecting microscope and suturing the open ends of the vessel with surgical thread before enzymatic disruption. The vessels were everted and incubated in $0.1 \%$ collagenase for $15 \mathrm{~min}$ and then $0.1 \%$ trypsin for $15 \mathrm{~min}$ to remove the endothelial cell layer. The washed vessels were then treated with $0.05 \%$ elastase and $0.1 \%$ collagenase, without stirring, for $2 \mathrm{~h}$ at $37^{\circ} \mathrm{C}$, in $95 \% \mathrm{O}_{2} / 5 \% \mathrm{CO}_{2}$. After digestion, the resulting tissue-cell suspension was filtered through a $100 \mu \mathrm{M}$ nylon mesh and the filtrate treated with $20 \%$ fetal calf serum (FCS) to inactivate the

1. Abbreviations used in this paper: DEX, dexamethasone; IGF-I, insulin-like growth factor-I; PDGF, platelet-derived growth factor; PTHrP, parathyroid hormone-related protein; SMC, smooth muscle cell(s). 
enzymes. Cells were centrifuged, and the pellet resuspended in Iscove's modified Dulbecco's minimal essential medium supplemented with $10 \%$ FCS, L-glutamine, and antibiotics as described (17). Cells were seeded at a density of $5 \times 10^{4}$ cells cm $\mathrm{cm}^{-2}$ in $50-\mathrm{cm}^{2}$ culture dishes and maintained at $37^{\circ} \mathrm{C}$ in a humidified atmosphere of $95 \% \mathrm{O}_{2} / 5 \% \mathrm{CO}_{2}$, with media changes every $2 \mathrm{~d}$. Cells were passaged when confluent by treatment with a mixture of trypsin and collagenase. For these studies we used cells from passages 4 through 6 which retained phenotypic properties consistent with SMC: a hill-and-valley pattern of growth in confluent cultures, nodule formation, and specific immunocytochemical staining of $\alpha$-actin.

Total RNA extraction and Northern blot analysis. Total RNA was extracted according to the method of Chirgwin et al. (18) with slight modifications. $50 \mu \mathrm{g}$ of total RNA (from two confluent T-75 flasks) was electrophoresed on $1.5 \%$ agarose, formaldehyde gels containing ethidium bromide. RNA samples were transferred onto nylon membranes and then hybridized to a PTHrP cDNA probe (rPLPm9) labeled with $\left[{ }^{32} \mathrm{P}\right] \mathrm{CTP}$ by a random primer method (19). The cDNA probe encodes most of the coding region and the 3'-untranslated region of rat PTHrP (10). In some cases the blots were reprobed with a c-myc cDNA probe (pHSR-1, provided by J. M. Bishop, University of California, San Francisco), or a cDNA probe for rat cyclophilin (BamHI restriction fragment from plasmid pCD15.8.1 [20]). Filters were washed three times

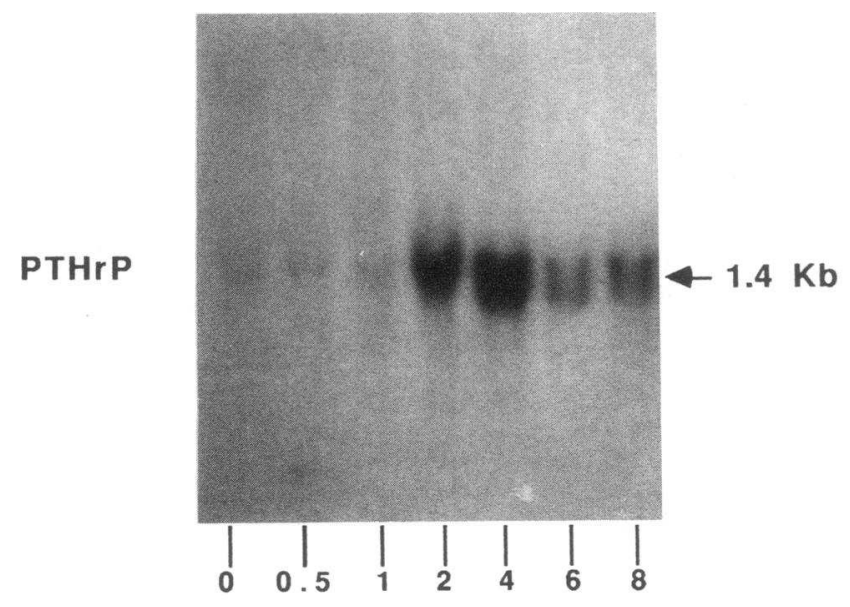

Time (hours)

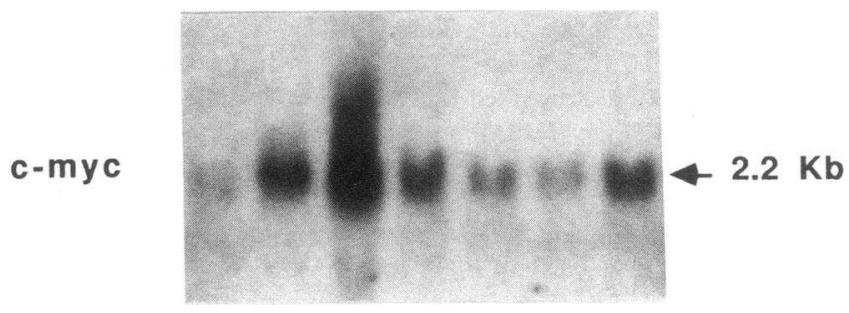

Figure 1. Time course of the induction of PTHrP mRNA in aortic SMC. Confluent cells were deprived of serum for $5 \mathrm{~d}$ then exposed to medium containing $10 \%$ FCS. Total RNA was extracted from duplicate T-75 flasks at the indicated times and $50 \mu \mathrm{g}$ was assayed by Northern blotting as described in the Methods section. A single mRNA transcript of $\sim 1.4 \mathrm{~kb}$ was expressed in low abundance in serum-deprived cells and was markedly induced with a peak at $4 \mathrm{~h}$. The bottom panel shows the more rapid appearance of c-myc mRNA in the same cells after serum addition as determined by washing and reprobing the same filter with a c-myc cDNA probe. This blot (and each of the subsequent illustrations) are representative of two to three separate experiments.

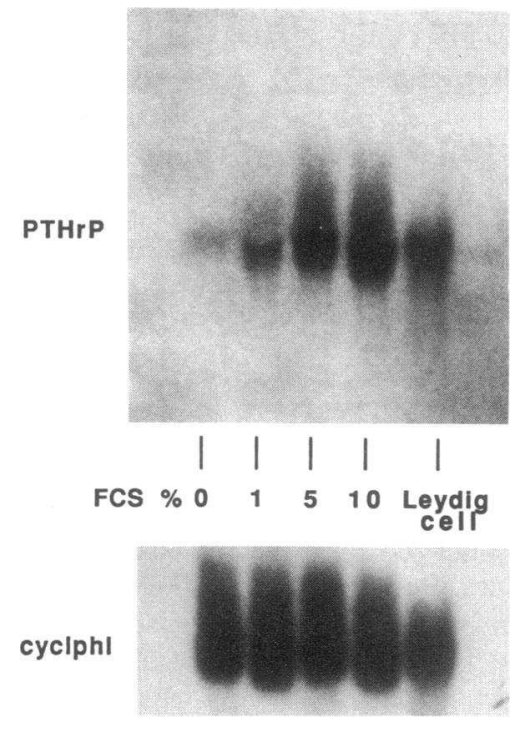

Figure 2. Serum concentration-dependence for serum induction of PTHrP mRNA in SMC. Serum-deprived cells were exposed to medium containing $10 \%$ FCS and total RNA was extracted after $4 \mathrm{~h}$ and assayed by Northern blotting. The content of PTHrP mRNA was maximum with $10 \%$ FCS. The far right lane shows the transcript detected from $50 \mu \mathrm{g}$ of total RNA of rat Leydig cell tumor tissue which can be seen to be of identical size to that seen in serum-stimulated SMC. The bottom panel shows the level of constitutive cyclophilin (cycphl) mRNA expression obtained by rehybridizing the blot with a c-DNA probe.

(30 min each) to a stringency of $0.1 \times \mathrm{SSC}, 0.1 \% \mathrm{SDS}$ at $55^{\circ} \mathrm{C}$ and exposed to X-omat film (Eastman Kodak Co., Rochester, NY) with intensifying screens at $-70^{\circ} \mathrm{C}$.

Determination of PTHrP effects on cell replication. The effect of recombinant PTHrP-(1-141) on SMC DNA synthesis was assessed by incorporation of $\left[{ }^{3} \mathrm{H}\right]$ thymidine into acid precipitable DNA. Cells were plated into 96-well microtiter dishes and grown to confluence in Iscove's modified Dulbecco's minimal essential medium containing $10 \%$ FCS. Cells were maintained in serum-free medium for $5 \mathrm{~d}$ and then treated with PTHrP-(1-141) or PTH-(1-34) $\mathrm{NH}_{2}$ at a final concentration of 1,10 , or $100 \mathrm{ng} / \mathrm{ml}$. (The biological activity of each of the peptides was confirmed in vivo [5] in our thyroparathyroidectomized rat model.) $\left[{ }^{3} \mathrm{H}\right]$ Thymidine incorporation in cells receiving $10 \%$ FCS was used as a positive control. After $18 \mathrm{~h}$ of exposure to each treatment, $\left[{ }^{3} \mathrm{H}\right]$ thymidine $(1 \mu \mathrm{Ci} / \mathrm{ml})$ was added to each well and its incorporation into trichloroacetic acid-precipitable DNA was determined after $6 \mathrm{~h}$ by liquid scintillation counting.

Immunocytochemistry of PTHrP. Cells were rinsed with PBS and fixed in $4 \%$ phosphate-buffered paraformaldehyde for $1 \mathrm{~h}$. Fixed cells were washed twice with $0.1 \mathrm{M}$ Tris, $\mathrm{pH} 7.5$, and then subjected to an indirect, immunoperoxidase cytochemical procedure as described (21, 22). In brief, monolayers were incubated overnight with an affinity purified monoclonal antibody against PTHrP (Oncogene Science, Manhassett, NY). Cells were then reacted with $1 \mu \mathrm{g} / \mathrm{ml}$ of peroxidaseconjugated anti-mouse IgG for $\mathrm{l} \mathrm{h}$ at room temperature and developed with $0.05 \%$ 3,3'-diaminobenzidine tetrahydrochloride (PolySciences, Inc., Warrington, PA) with $0.3 \%$ glucose oxidase, $0.4 \mathrm{mg} / \mathrm{ml}$ ammonium chloride, and $2 \mathrm{mg} / \mathrm{ml} \mathrm{D}(+)$ glucose. Control monolayers were incubated with a nonimmune mouse IgG in place of the primary antibody.

Radioimmunoassay of PTHrP. PTHrP was measured in SMC conditioned medium before and after serum exposure using a radioimmunoassay. Confluent cells in 12-well cluster plates were deprived of serum for $5 \mathrm{~d}$ then exposed to $10 \%$ FCS for various times up to $24 \mathrm{~h}$. Conditioned medium $(200 \mu \mathrm{l})$ was removed and assayed for PTHrP using a commercial kit (INCStar, Stillwater, MN) with one modification. The standard PTHrP-(1-34) was diluted in culture medium containing $10 \%$ FCS in place of the standard diluent. Fetal calf serum was added to conditioned medium from serum-free cultures to give a final concentration of $10 \%$. The limit of detection of this assay was $1.8 \mathrm{pmol} /$ liter. 


\section{Results}

PTHrP RNA expression in SMC. We first examined PTHrP mRNA levels by Northern blot analysis in SMCs cultured in the absence or presence of serum (10\%)-containing medium at different stages of confluency. We detected a single mRNA species of $1.4 \mathrm{~kb}$ consistent with the size of rat PTHrP mRNA shown previously $(11,12)$, and with the size of the transcript detected in RNA from a rat Leydig cell tumor (23), which we included as a positive control. PTHrP mRNA was expressed at low abundance in cells grown in the absence of serum and was clearly increased in growing cells exposed continuously to serum (data not shown). The abundance of PTHrP mRNA appeared to change little as a function of confluency as demonstrated in cells cultured for up to $13 \mathrm{~d}$ in serum-containing medium. PTHrP mRNA was also clearly detected in adult rat aorta (data not shown).

The time course of serum induction of PTHrP mRNA was studied in confluent cells deprived of serum for $5 \mathrm{~d}$, and then exposed to medium containing $10 \%$ FCS. The addition of serum resulted in a striking induction of PTHrP mRNA within $2 \mathrm{~h}$ (Fig. 1). PTHrP mRNA levels were maximal at $4 \mathrm{~h}$ and fell rapidly thereafter. By $8 \mathrm{~h}$ PTHrP mRNA expression persisted at a level slightly above that observed under serum-free conditions (Fig. 1). To further characterize the early phase of PTHrP mRNA induction we compared the time course of c-myc mRNA expression, a gene known to be rapidly induced by serum in SMC (24), by reprobing the same blot with a human c-myc cDNA probe. Serum stimulated c-myc mRNA to maximum levels by $1 \mathrm{~h}$ as compared to the later peak (4 h) observed for PTHrP mRNA expression (Fig. 1). The serum induction of PTHrP mRNA was concentration-dependent as demonstrated in Fig. 2.

Effect of metabolic inhibitors on serum-induction of PTHrP $m R N A$ content. To study the mechanisms by which serum regulates PTHrP gene expression in SMC, we determined PTHrP mRNA levels in cells after treatment with actinomycin $D$ or cycloheximide to inhibit gene transcription and protein synthe-

\section{Time (hours)}
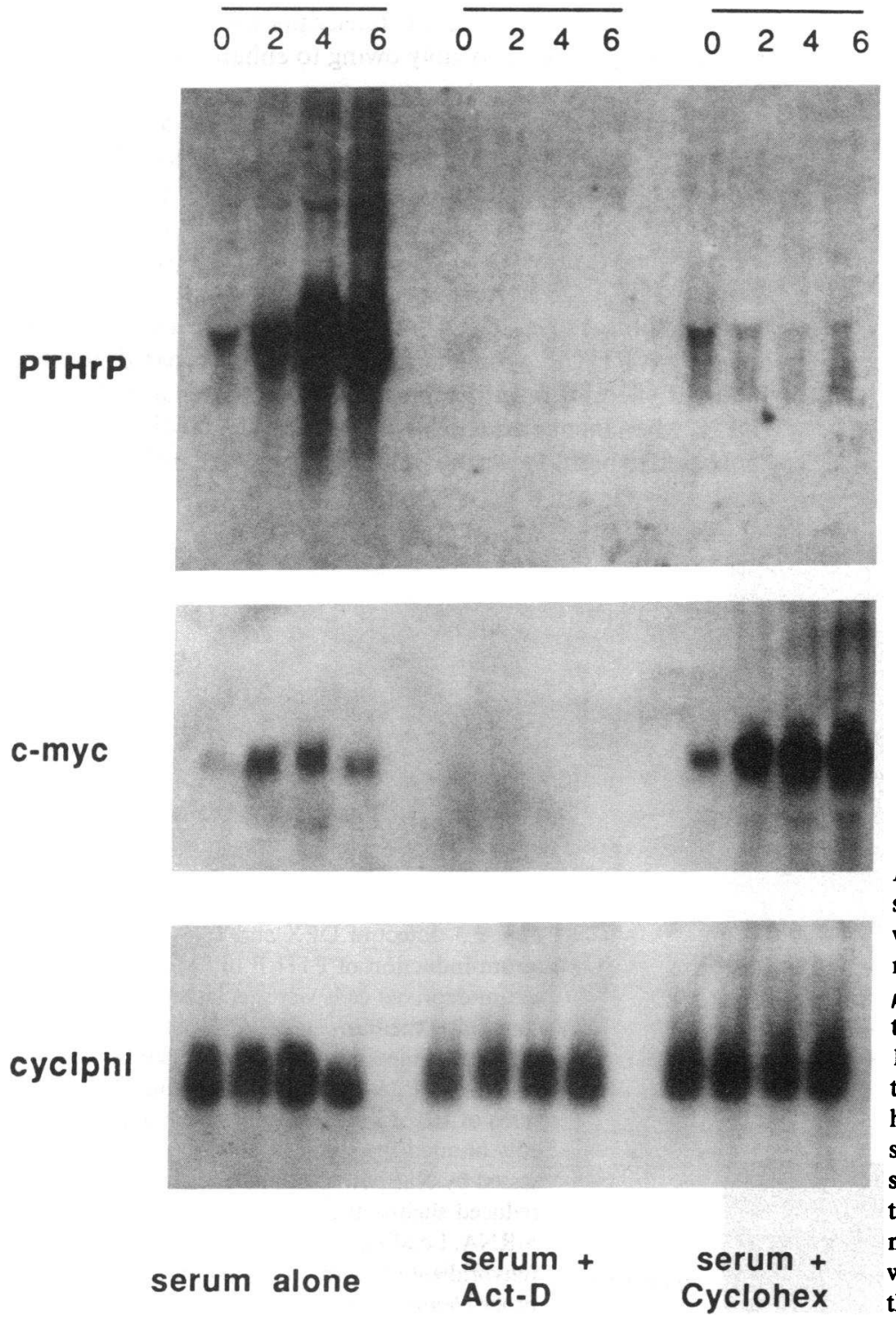

Figure 3. Effect of actinomycin-D and cycloheximide on serum-induction of PTHrP mRNA in SMC. Confluent cells were deprived of serum for $\mathbf{5} \mathbf{d}$ and then exposed to fresh medium containing no inhibitor or either actinomycin $\mathrm{D}(5$ $\mu \mathrm{g} / \mathrm{ml})$ or cycloheximide $(10 \mu \mathrm{g} / \mathrm{ml}) .2 \mathrm{~h}$ later FCS was added to cells in each treatment group to a final concentration of $10 \%$. Actinomycin-D completely blocked the serum induction of PTHrP mRNA, whereas prior treatment with cycloheximide blocked the induction but not the "basal" expression. Reprobing the blot with a c-myc cDNA (middle panel) shows the expected abolition of mRNA expression after actinomycin-D treatment and the progressive increased accumulation of mRNA in cells treated with cycloheximide which has been previously reported. The bottom panel shows the level of cyclophilin (cycphl) mRNA expression. 


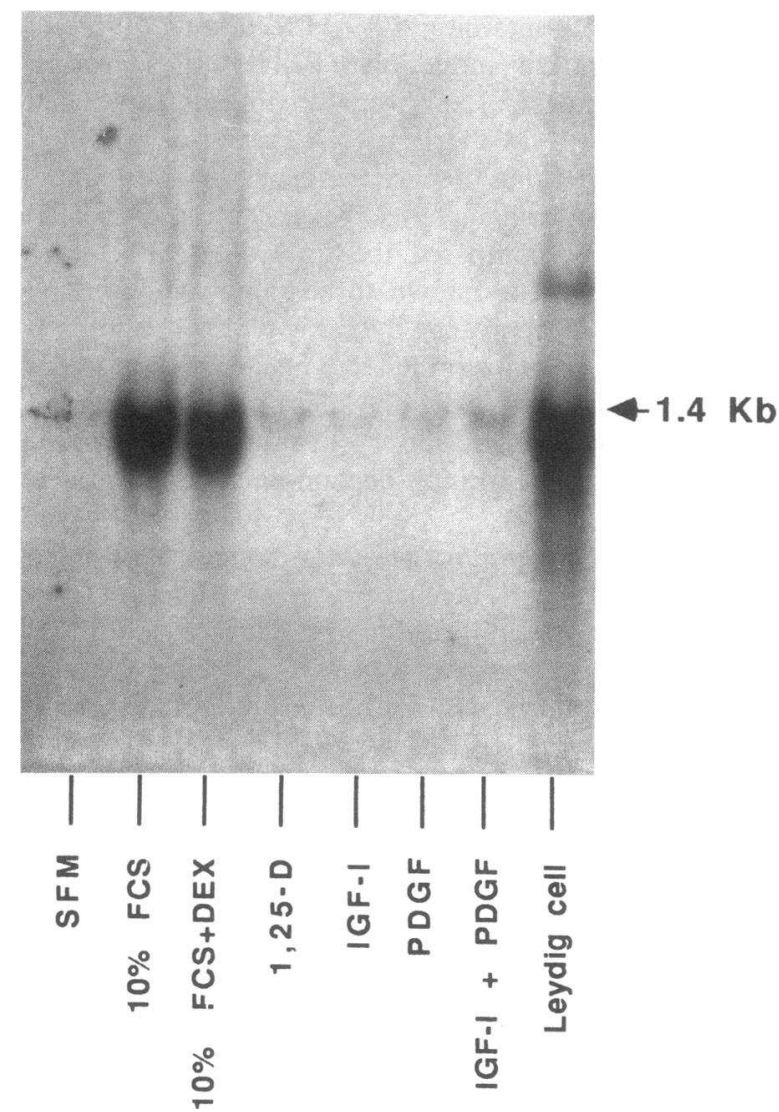

Figure 4. Effect of hormones and growth factors on PTHrP mRNA in SMC. Serum-deprived cells were treated with serum-free medium alone ( far left lane) or medium with $10 \%$ FCS alone or in combination with DEX $\left(10^{-8} \mathrm{M}\right)$, or the following agents in the absence of serum: $1,25-(\mathrm{OH})_{2} \mathrm{D}_{3}\left(10^{-8}\right)$, IGF-I $(25 \mathrm{ng} / \mathrm{ml})$, PDGF $(10 \mathrm{ng} / \mathrm{ml})$, IGF-I plus PDGF. The Leydig cell tumor control is included as a control. sis, respectively. Cells grown in serum-free medium for $5 \mathrm{~d}$ were treated with actinomycin $\mathrm{D}(5 \mu \mathrm{g} / \mathrm{ml})$ or cycloheximide $(10 \mu \mathrm{g} / \mathrm{ml})$ for $2 \mathrm{~h}$ and then exposed to $10 \% \mathrm{FCS}$. These doses of each inhibitor effectively inhibited RNA and protein synthesis (as measured by incorporation of $\left[{ }^{3} \mathrm{H}\right]$ uridine and $\left[{ }^{3} \mathrm{H}\right]$ leucine) but did not affect cell viability as assessed by trypan blue dye exclusion. RNA was extracted 2,4 , and $6 \mathrm{~h}$ after serum addition and compared to that from cells that did not receive inhibitor. Prior treatment with actinomycin-D blocked both the constitutive expression as well as the serum induction of PTHrP mRNA, reducing mRNA levels to below those seen in serumfree cultures. Cycloheximide also blocked the induction of PTHrP mRNA but did not abolish constitutive expression (Fig. 3). These data suggest that the acute serum induction of PTHrP depends on new protein synthesis, whereas the constitutive expression of the gene (at least through $6 \mathrm{~h}$ ) does not.

To further confirm the effectiveness of the inhibitors in this experiment, the same blot was reprobed with a c-myc cDNA probe (Fig. 3, middle panel). As expected, actinomycin D eliminated the serum induction of $c-m y c$ mRNA whereas cycloheximide treatment resulted in a progressive increase in c-myc mRNA content above that observed by addition of serum alone. This effect has been demonstrated previously in aortic SMC (24) and represents post-transcriptional regulation of cmyc gene expression probably owing to enhanced mRNA stability.

Effects of growth factors, hormones, and vasoactive agents on PTHrP gene expression. Selected proteins and steroids present in serum with established growth altering activity in SMC and other cells were evaluated for their ability to influence PTHrP gene expression in SMC grown in serum-free medium. Neither IGF-I $(25 \mathrm{ng} / \mathrm{ml})$ nor PGDF $(10 \mathrm{ng} / \mathrm{ml})$, alone or in combination, nor $1,25-(\mathrm{OH})_{2} \mathrm{D}_{3}\left(10^{-8} \mathrm{M}\right)$ had any apparent effect on PTHrP gene expression when compared to the marked effect of serum (Fig. 4). On the other hand, $10^{-8} \mathrm{M}$ DEX, when incubated with serum containing medium for $4 \mathrm{~h}$, appeared to blunt the serum induction of PTHrP mRNA. How-
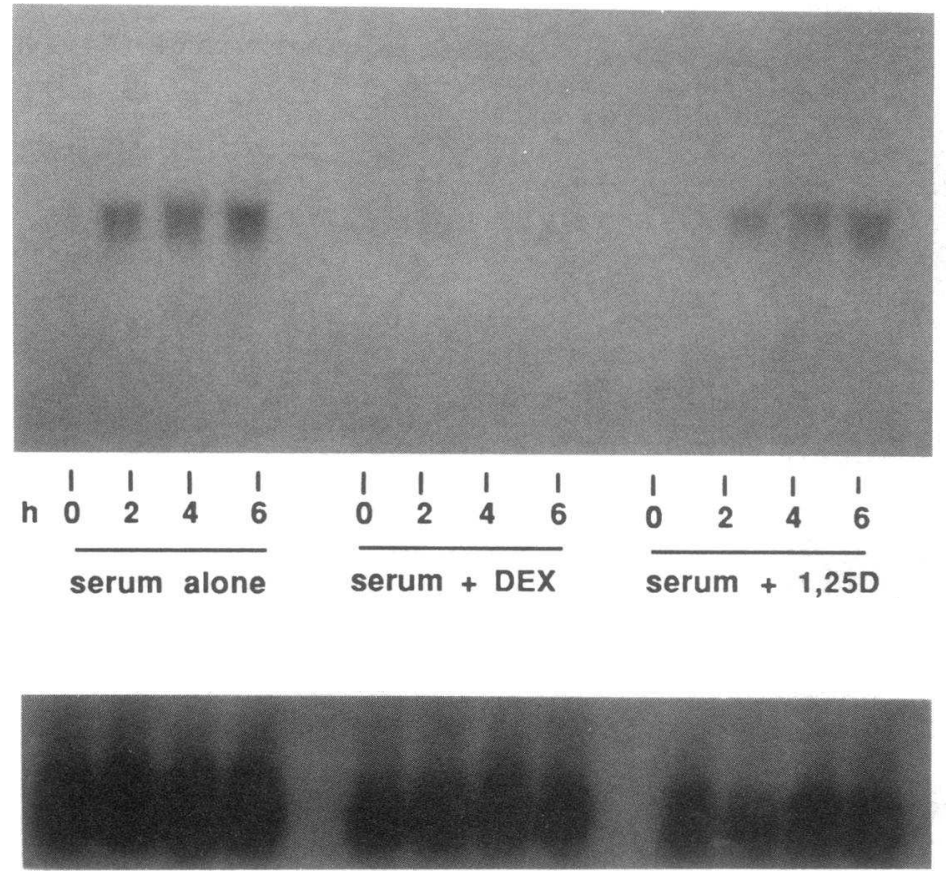

cyclphl
Figure 5. Effect of DEX and 1,25- $(\mathrm{OH})_{2} \mathrm{D}_{3}$ on serum-induction of PTHrP in SMC. Confluent, serum-deprived cells were replaced with $5 \%$ FCScontaining medium alone (left lanes) or serum containing medium with $0.01 \%$ ethanol (control), or DEX or $1,25-(\mathrm{OH})_{2} \mathrm{D}_{3}$, both at final concentrations of $10^{-8} \mathrm{M}$ in the same vehicle. DEX markedly blunted the serum-induction of PTHrP as assessed by Northern blot analysis. 1,25- $(\mathrm{OH})_{2} \mathrm{D}_{3}$ reduced slightly the serum stimulation of PTHrP mRNA. Loading among lanes was monitored by rehybridization with a cyclophilin (cycphl) cDNA probe (bottom panel). 


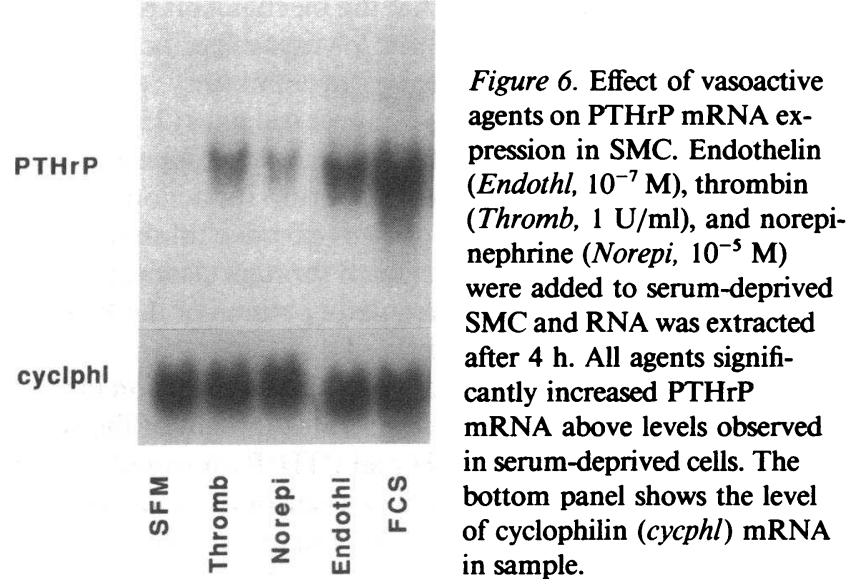

ever, DEX alone $\left(10^{-8} \mathrm{M}\right)$ had no detectable effect on PTHrP mRNA expression (data not shown). Since previous studies have shown that both DEX and 1,25- $(\mathrm{OH})_{2} \mathrm{D}_{3}$ inhibit PTHrP gene expression in human cancer cells $(25,26)$, we further determined the effect of these hormones on the serum induction of PTHrP gene expression. Serum-deprived, confluent cells were treated with medium containing 5\% FCS (a submaximal dose for stimulation of PTHrP mRNA) containing either $10^{-8}$ $\mathrm{M}$ DEX or $10^{-8} \mathrm{M} 1,25-(\mathrm{OH})_{2} \mathrm{D}_{3}$ dissolved in ethanol (final concentration: $0.01 \%$ ). Control cultures received $5 \%$ FCS containing $0.01 \%$ ethanol. Both agents reduced the serum induction of PTHrP mRNA as compared to controls at 4 and $6 \mathrm{~h}$. However, under these conditions, DEX was a much more effective inhibitor compared to $1,25-(\mathrm{OH})_{2} \mathrm{D}_{3}$ (Fig. 5).

Several vasoactive peptides were also tested for their effects on PTHrP mRNA expression in serum deprived SMC. Endothelin $\left(10^{-7} \mathrm{M}\right)$ markedly induced PTHrP mRNA to levels approaching those observed in serum-treated cells (Fig. 6). Thrombin $(1 \mathrm{U} / \mathrm{ml})$ and norepinephrine $\left(10^{-5} \mathrm{M}\right)$ also induced
PTHrP mRNA above serum-free levels but were less effective than endothelin.

Immunochemical detection of PTHrP in SMC. PTHrP was detected in SMC using immunocytochemistry and was shown to be induced by serum. Addition of $10 \%$ FCS to serum-deprived cells was associated with an increase in immunostaining relative to cells maintained in serum-free medium (Fig. 7). Detectable increases in PTHrP-like immunoreactivity were evident $16-24 \mathrm{~h}$ after addition of serum.

PTHrP accumulation in medium from serum treated SMC was also detected by radioimmunoassay (Fig. 8). Concentrations rose from undetectable levels $(<1.8 \mathrm{pmol} / \mathrm{liter})$ in serumdeprived cells to peak levels of 4-5 pmol/liter by $12 \mathrm{~h}$. Similar results were obtained in a separate experiment.

Effect of PTHrP on SMC DNA synthesis. To investigate the potential influence of PTHrP on SMC proliferation we determined the effect of exogenous peptide on DNA synthesis. Recombinant PTHrP-(1-141) added to serum-deprived cells at 1 , 10 , and $100 \mathrm{ng} / \mathrm{ml}$ for $18 \mathrm{~h}$ had no significant effect on $\left[{ }^{3} \mathrm{H}\right]-$ thymidine incorporation (Fig. 9). By contrast, addition of medium containing $10 \%$ FCS significantly $(P<0.001)$ increased incorporation from $1,897 \pm 406$ to $10,606 \pm 1037 \mathrm{cpm}$ (mean \pm SEM). PTH-(1-34) $\mathrm{NH}_{2}$ at a dose of $10 \mathrm{ng} / \mathrm{ml}$ had no significant effect on DNA synthesis. Two separate experiments reproduced these findings. Furthermore, addition of $10 \mathrm{ng} / \mathrm{ml}$ PTHrP-(1-141) failed to inhibit $\left[{ }^{3} \mathrm{H}\right]$ thymidine incorporation in SMC stimulated by $2 \%$ or $5 \%$ FCS (data not shown).

\section{Discussion}

Our studies demonstrate that PTHrP and its mRNA are expressed by vascular smooth muscle cells in primary culture and are markedly and acutely up-regulated when cells are exposed to serum. In confluent, growth-arrested cells PTHrP mRNA was expressed at levels below those observed in growing cells. The extraordinary increment in PTHrP mRNA seen within $4 \mathrm{~h}$
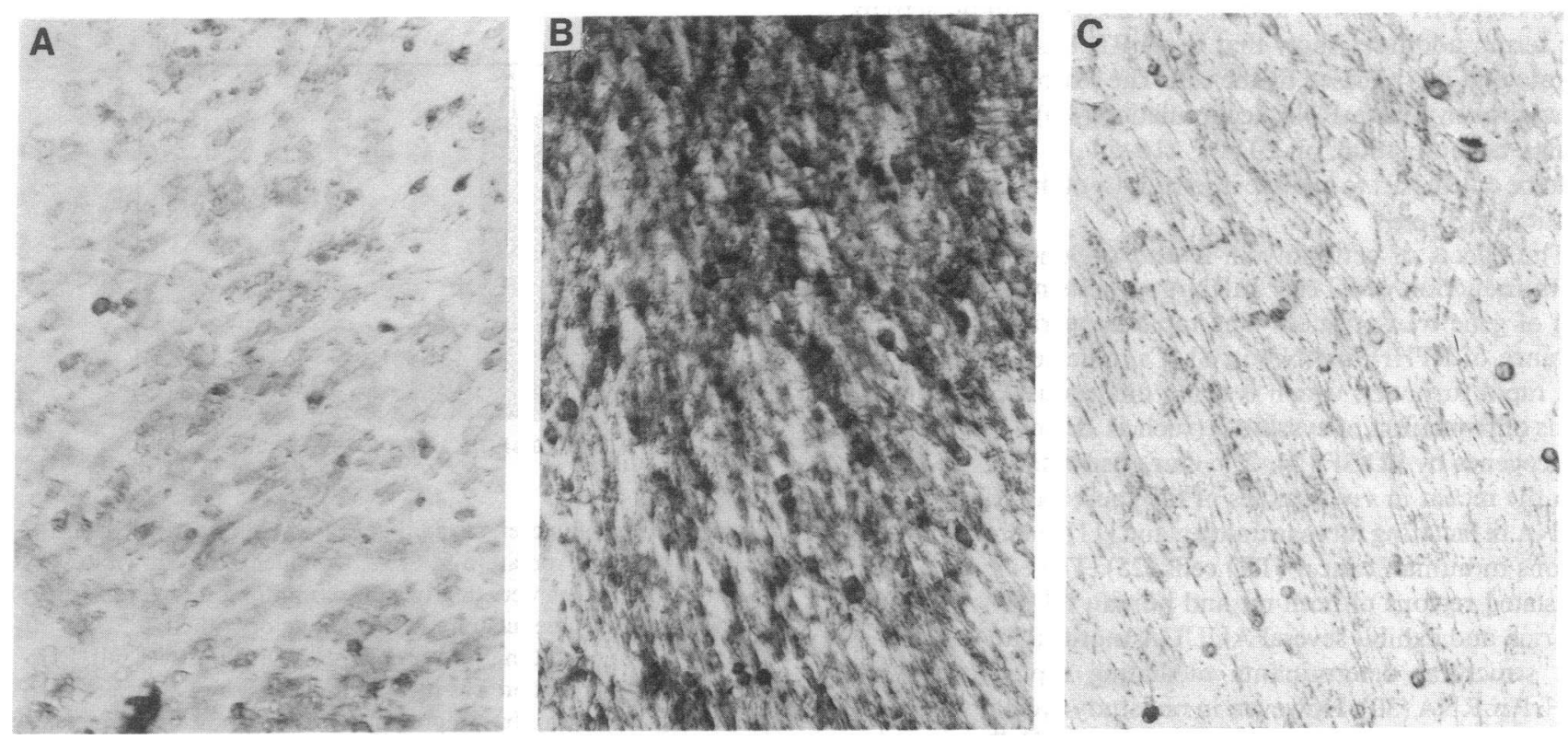

Figure 7. Immunocytochemical detection of PTHrP in SMC. Confluent cells were fixed and immunostained as described in the Methods section. SMC maintained in serum-free medium demonstrated moderate cytoplasmic PTHrP immunoreactivity $(A)$, which was clearly increased in SMC $24 \mathrm{~h}$ after exposure to serum $(B)$. Panel $C$ shows the background staining in serum stimulated cells reacted with a nonimmune mouse IgG. (Initial magnification $\times 200$ ). 


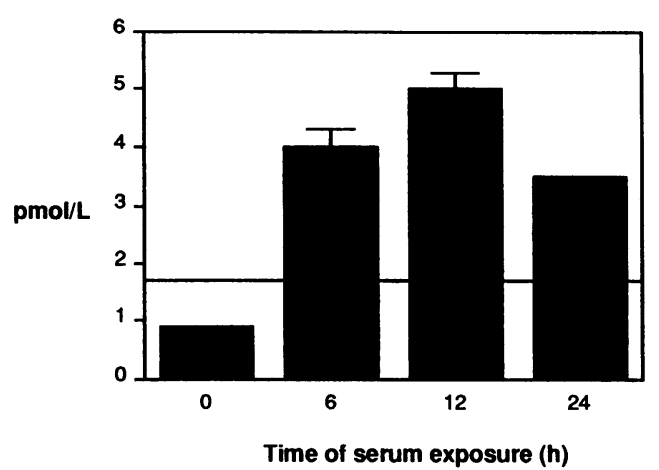

Figure 8. Detection of PTHrP in SMC conditioned medium by radioimmunoassay. SMC were deprived of serum for $5 \mathrm{~d}$ then exposed to $10 \%$ FCS. Medium $(200 \mu \mathrm{l})$ collected at the indicated times was assayed using a PTHrP radioimmunoassay as described in the Methods section. Accumulation of immunoreactive PTHrP was maximal at $12 \mathrm{~h}$ after serum addition. The horizontal line indicates the assay detection limit ( $1.8 \mathrm{pmol} /$ liter). The results are from replicate (two to three) wells. Error bars represent the standard deviation of mean values.

after addition of FCS to serum-deprived cells, and its transient expression, is analogous to the response of other cytokine mRNA in NIH 3 T 3 cells (27) and lymphocytes (28) after stimulation of cell proliferation. It is interesting, however, that the well recognized mesenchymal cell mitogens, PDGF and IGF-I $(17,29)$, did not affect PTHrP mRNA gene expression. Since both of these peptides are known to induce expression of the early response genes c-fos and c-myc in SMC (24), the serum induction of PTHrP is not simply a secondary response to events after induction of these oncogenes. It seems likely that the intervening expression of another gene mediates the acute serum response, since it is blocked by cycloheximide. Thus, PTHrP gene expression appears to be regulated in a specific manner by a factor(s) in serum. The immunocytochemical detection of PTHrP in SMC, and the increased immunoreactivity after serum addition, show that the mRNA is translated and indicate that it is released by the cell. The reason for the apparent lag time in peak mRNA accumulation $(4 \mathrm{~h})$ and maximum cellular accumulation of PTHrP (16-24 h) is unclear, but might be due in part to relative insensitivity of the immunocytochemical method.

The effects of actinomycin-D and cycloheximide on the serum induction of PTHrP mRNA suggests regulation at the level of gene transcription. The rapid appearance and disappearance of PTHrP mRNA in SMCs indicates that it undergoes rapid turnover, which is again analogous to the mechanisms of regulation of cytokines (such as JE and $\mathrm{KC}$ ) and protooncogenes by PDGF $(24,27)$. Our observation is consistent with the recent in vivo studies of the short half-life of PTHrP mRNA in lactating rat mammary gland (11) and in vitro observations in human cancer (TT) cells (25). The extensive 3'-untranslated regions of both rat and human PTHrP mRNA are AU rich and exhibit several AUUUA motifs that could represent structural determinants mediating rapid turnover of PTHrP mRNA (30). However, in our study cycloheximide had no apparent effect on the constitutive PTHrP expression, which is opposite from previous findings of Ikeda et al. (31), who demonstrated an increase in PTHrP mRNA accumulation in various PTHrP-producing cell lines treated with this inhibitor. It is likely, therefore, that the mechanisms regulating PTHrP gene expression are cell and/or tissue specific.

DEX and 1,25-(OH) ${ }_{2} D_{3}$ have an inhibitory effect on PTHrP gene expression in human cancer cell lines $(25,26)$ and in human keratinocytes (32). Our preliminary studies in SMC show DEX also markedly inhibits the serum induction PTHrP mRNA whereas $1,25-(\mathrm{OH})_{2} \mathrm{D}_{3}$ is a less effective inhibitor. It is possible that these effects are mediated through classical receptor response elements in the 5 ' regulatory region of the PTHrP gene, but these have yet to be defined.

The physiological implications of PTHrP expression in vascular smooth muscle may be considerable in light of the welldocumented effects of both PTH and PTHrP on vascular tone (14). Both peptides are established vasorelaxants producing hypotensive actions when tested in vivo and in vitro. In addition, we have demonstrated that vasoactive peptides, most notably endothelin, are effective inducers of PTHrP mRNA in quiescent SMC. These findings suggest the intriguing possibility that PTHrP might act as an autocrine factor regulating the state of vessel contractility. Alternatively, PTHrP might function as a local factor, analogous to IGF-I which is known to modulate smooth muscle cell proliferation and differentiation during tissue growth and in response to vascular injury (33). Our failure to demonstrate an effect of exogenous PTHrP does not preclude a role for this protein in SMC proliferation which might require the presence of other cofactors.

In addition to vascular smooth muscle, increasing evidence suggests that PTHrP has important functions in other smooth muscle tissue. For example, in chicken oviduct, the expression of PTHrP mRNA by the egg shell gland smooth muscle coincides temporally with oviduct development and the arrival of the egg in the shell gland (34). In addition, other studies have shown that intrauterine occupancy of fetus in the gravid rat placenta triggers PTHrP gene expression in the muscularis layer (35). Therefore, it is apparent that smooth muscle is a major site of PTHrP production, although its function remains to be established. Moreover, while it is attractive to envision

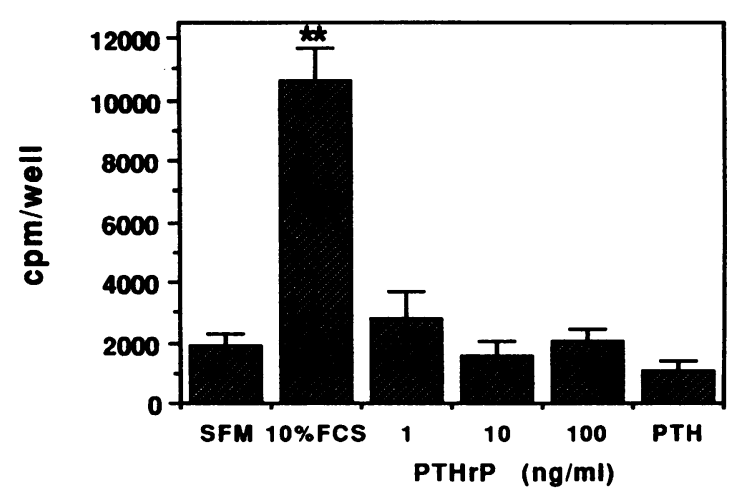

Figure 9. Effect of exogenous addition of recombinant PTHrP on $\left[{ }^{3} \mathrm{H}\right]$ thymidine incorporation in SMC. Confluent cells grown in 96well microtiter plates were deprived of serum for $5 \mathrm{~d}$ then replaced with either serum-free medium $(S F M)$ alone or with $10 \%$ FCS, PTHrP-(1-141), (1-100 ng/ml), or PTH-(1-34) $\mathrm{NH}_{2}(10 \mathrm{ng} / \mathrm{ml})$. $\left[{ }^{3} \mathrm{H}\right]-$ Thymidine incorporation was measured after $18 \mathrm{~h}$ of exposure to these conditions. Error bars represent the mean $( \pm$ SEM) cpm for five to six wells. Neither PTHrP nor PTH had any significant $(P>0.05)$ effect on $\left[{ }^{3} \mathrm{H}\right]$ thymidine incorporation compared to the marked stimulation in cells exposed to $10 \%$ serum. Similar results were obtained in two separate experiments. ${ }^{* *} P<0.001$ vs. serum-free medium. 
the concept of PTHrP as an autocrine regulator of growth or contractility in this tissue, it is still unclear which forms of PTHrP are released from SMC, or whether its function requires cellular secretion. In addition, PTHrP did not influence SMC replication in our study, which contrasts with results in lectin-stimulated human $\mathrm{T}$ lymphocytes in which growth was inhibited by PTHrP (36).

In summary, our studies show for the first time that PTHrP is a major product of normal aortic smooth muscle cells and is regulated in a manner that would suggest a fundamental role in this tissue. The relative abundance of its mRNA in these cells, together with the availability of recently cloned cDNA and genomic DNA probes for this protein should facilitate further study of the factors regulating PTHrP expression and the exploration of its possible function in vascular smooth muscle.

\section{Acknowledgments}

The authors wish to thank Amin Kamyar for expert technical assistance.

This work was supported in part by National Institutes of Health grants CA-50906, CA-50706, and CA-52495 and grants from the Medical Research Council and National Cancer Institute of Canada.

\section{References}

1. Moseley, J. M., M. Kubota, H. Diefenback-Jagger, R. E. H. Wettenhall, B. E. Kemp, L. J. Suva, C. P. Rodda, P. R. Ebeling, P. J. Hudson, J. D. Zajac, et al 1987. Parathyroid hormone-related protein purified from a human lung cancer cell line. Proc. Natl. Acad. Sci. USA. 84:5048-5052.

2. Stewart, A. F., T. Wu, D. Goumas, W. J. Burtis, and A. E. Broadus. 1987 $\mathrm{N}$-Terminal amino acid sequence of two novel tumor-derived adenylate cyclasestimulating proteins: identification of parathyroid hormone-like and parathyroid hormone-unlike domains. Biochem. Biophys. Res. Commun. 146:672-678.

3. Strewler, G. J., H. Stern, J. W. Jacobs, J. Eveloff, R. F. Klein, S. C. Leung, M. Rosenblatt, and R. A. Nissenson. 1987. Parathyroid hormone-like protein from human renal carcinoma cells. J. Clin. Invest. 80:1803-1807.

4. Kemp, B. E., J. M. Moseley, C. P. Rodda, P. R. Ebeling, R. E. H. Wettenhall, D. Stapleton, H. Deifenback-Jagger, F. Ure, V. P. Michaelangeli, H. A. Simmons, et al. 1987. Parathyroid hormone-related protein of malignancy: active synthetic fragments. Science (Wash. DC). 238:1568-1570.

5. Horiuchi, N., M. P. Caulfield, J. E. Fisher, M. E. Goldman, R. L. McKee, J. E. Reagan, J. J. Levy, R. F. Nutt, S. B. Rodan, T. L. Schofield, et al. 1987 Similarity of synthetic peptide from human tumor to parathyroid hormone in vivo and in vitro. Science (Wash. DC). 238:1566-1568.

6. Yates, A. J. P., G. E. Gutierrez, P. Smolens, P. S. Travis, M. S. Katz, T. B. Aufdemorte, B. F. Boyce, T. K. Hymer, J. W. Poser, and G. R. Mundy. 1988 Effects of synthetic peptide of parathyroid hormone-related protein on calcium homeostasis, renal tubular calcium reabsorption and bone metabolism in vivo and in vitro in rodents. $J$. Clin. Invest. 81:932-938.

7. Mangin, M., K. Ikeda, B. E. Dreyer, and A. E. Broadus. 1989. Isolation and characterization of the human parathyroid hormone-like peptide gene. Proc. Natl. Acad. Sci. USA. 86:2408-2412.

8. Yasuda, T., D. Banville, G. N. Hendy, and D. Goltzman. 1989. Characterization of the human parathyroid hormone-like peptide gene: functional and evolutionary aspects. J. Biol. Chem. 264:7720-7725.

9. Ikeda, K., E. C. Weir, M. Mangin, P. S. Dannies, B. Kinder, L. J. Deftos, E. M. Brown, and A. E. Broadus. 1988. Expression of messenger ribonucleic acids encoding a parathyroid hormone-like peptide in normal human and animal tissues with abnormal expression in human parathyroid adenomas. Mol. Endocrinol. 2:1230-1236.

10. Karaplis, A. C., T. Yasuda, G. N. Hendy, D. Goltzman, and D. Banville. 1990. Gene encoding parathyroid hormone-like peptide: nucleotide sequence of the rat gene and comparison with the human homologue. Mol. Endocrinol. 4:441-446.

11. Thiede, M. A., and G. A. Rodan. 1988. Expression of a calcium-mobilizing parathyroid hormone-like peptide in lactating mammary tissues. Science (Wash. DC). 242:278-280.

12. Yasuda, T., D. Banville, S. A. Rabbani, G. N. Hendy, and D. Goltzman. 1989. Rat parathyroid hormone-like peptide: comparison with the human homologue and expression in malignant and normal tissue. Mol. Endocrinol. 3:518525 .

13. Rodda, C. P., M. Kubota, J. A. Heath, P. R. Ebeling, J. M. Moseley, A. D.
Care, I. W. Caple, and T. J. Martin. 1988. Evidence for a novel parathyroid hormone-related protein in fetal lamb parathyroid glands and sheep placenta: Comparisons with a similar protein implicated in humoral hypercalcaemia of malignancy. J. Endocrinol. 117:261-271.

14. Mok, L. L. S., G. A. Nichols, J. C. Thompson, and C. W. Cooper. 1989. Parathyroid hormone as a smooth muscle relaxant. Endocrine Rev. 10:420-436.

15. Orloff, J. J., T. L. Wu, D. Goumas, and A. F. Stewart. 1989. Receptors for Parathyroid hormone-like peptide in vascular smooth muscle cells. Clin. Res. 37:457A. (Abstr.)

16. Chamley-Campbell, J., G. R. Campbell, and R. Ross. 1979. The smooth muscle cell in culture. Physiol. Rev. 59:1-61.

17. Walker, L. N., D. F. Bowen-Pope, R. Ross, and M. A. Reidy. 1986. Production of platelet-derived growth factor-like molecules by cultured arterial smooth muscle cells accompanies proliferation after arterial injury. Proc. Natl. Acad. Sci. USA. 83:7311-7315.

18. Chirgwin, J. M., A. E. Przybyla, R. J. MacDonald, and W. J. Rutter. 1979. Isolation of biologically active ribonucleic acid from sources enriched in ribonuclease. Biochemistry. 18:5294-5299.

19. Feinberg, A. P., and G. Vogelstein. 1983. Addendum. A technique for radiolabelling DNA restriction endonuclease fragments to high specific activity. Anal. Biochem. 137:266-267.

20. Danielson, P. E., S. Forse-Petter, M. A. Brow, L. L. Calaretta, J. Douglass, R. J. Milner, and J. G. Sutcliff. 1988. A cDNA clone of the rat mRNA encoding cyclophilin. DNA (NY). 7:261-267.

21. Zhou, X-Y., D. W. Dempster, S. L. Marion, J. W. Pike, M. R. Haussler, and T. L. Clemens. 1986. Bone vitamin D-dependent calcium-binding protein is localized in chondrocytes of the growth-plate cartilage. Calcif. Tissue Int. 38:244 247.

22. Clemens, T. L., K. P. Garrett, X-Y. Zhou, J. W. Pike, M. R. Haussler, and D. W. Dempster. 1988. Immunocytochemical localization of the 1,25-dihydroxyvitamin $D_{3}$ receptor in target cells. Endocrinology. 122:1224-1230.

23. Rice, B. F., R. L. Ponthier, and M. D. Miller III. 1971. Hypercalcemia and neoplasia: a model system. Endocrinology. 88:1210-1216.

24. Kindy, M. S., and G. E. Sonenshein. 1986. Regulation of oncogene expression in cultured aortic smooth muscle cells. Post-transcriptional control of c-myc mRNA. J. Biol. Chem. 261:12865-12868.

25. Ikeda, K., C. Lu, E. C. Weir, M. Mangin, and A. E. Broadus. 1989. Transcriptional regulation of the parathyroid hormone-related protein by glucorticoids and vitamin D in a human C-cell line. J. Biol. Chem. 264:15743-15746.

26. Lu, C., K. Ikeda, J. J. Deftos, A. D. Gazdar, M. Mangin, and A. E Broadus. 1989. Glucocorticoid regulation of parathyroid hormone-related peptide gene transcription in a human neuroendocrine cell line. Mol. Endocrinol. 3:2034-2040.

27. Jones, S. D., D. J. Hall, B. J. Rollins, and C. D. Stiles. 1988. Platelet-derived growth factor generates at least two distinct intracellular signals that modulate gene expression. Cold Spring Harbor Symp. Quant. Biol. LIII:531-536.

28. Reed, J. C., J. D. Alpers, P. C. Nowell, and R. G. Glover. 1986. Sequential expression of protooncogenes during lectin-stimulated mitogenesis of normal human lymphocytes. Proc. Natl. Acad. Sci. USA. 83:3982-3986.

29. Clemmons, D. R., and J. J. Van Wyk. 1985. Evidence for a functional role of endogenously produced somatomedin-like peptides in the regulation of DNA synthesis in cultured human fibroblasts and porcine smooth muscle cells. J. Clin. Invest. 75:1914-1918.

30. Goltzman, D., G. N. Hendy, and D. Banville. 1989. Parathyroid hormone-like peptide: molecular characterization and biological properties. Trends Endocrinol. Metab. 1:39-44.

31. Ikeda, K., C. Lu, E. C. Weir, M. Mangin, and A. E. Broadus. 1990. Regulation of parathyroid hormone-related peptide expression by cycloheximide. J. Biol. Chem. 265:5398-5402.

32. Kremer, R., J. E. Henderson, A. C. Karaplis, W. Guilliver, D. Banville, G. N. Hendy, and D. Goltzman. 1990. Parathyroid hormone-like peptide: studies of gene regulation and expression. In Calcium Regulation and Bone Metabolism. D. V. Cohn, F. H. Glorieux, and T. J. Martin, editors. Elsevier, Amsterdam. 94-99.

33. Cercek, B., M. C. Fishbein, J. S. Forrester, R. H. Helfant, and J. A. Fagin. 1990. Induction of insulin-like growth factor-I messenger RNA in rat aorta after ballon dunudation. Circ. Res. 66:1750-1755

34. Theide, M. A., R. McKee, W. Grasser, and R. M. Leach. 1990. Potential role for PTH-related peptide in egg calcification: the stimulation of PTH-related peptide synthesis by the shell gland is correlated with egg movement down the avian oviduct. J. Bone. Min. Res. 5S:S76 (Abstr.).

35. Thiede, M. A., A. G. Daifotis, E. C. Weir, M. L. Brines, W. J. Burtis, K. Ikeda, B. E. Dreyer, R. E. Garfield, and A. E. Broadus. 1990. Intrauterine occupancy controls expression of the parathyroid hormone-related peptide gene expression in preterm rat myometrium. Proc. Natl. Acad. Sci. USA. 87:6969-6973.

36. Adachi, N., K. Yamaguchi, Y. Miyake, S. Honda, K. Nagasaki, Y. Akiyama, I. Adachi, and K. Abe. 1990. Parathyroid hormone-related protein is a possible autocrine growth inhibitor for lymphocytes. Biochem. Biophys. Res. Commun. 166:1088-1094. 